\title{
Comparative Children Literature: Aesthetic and Didactic Context
}

\section{Imron Wakhid Harits}

\begin{abstract}
Reading children literature is not merely deploying the cognitive activities for the learner's in the class, but reading children literature involves two important aspects to make the learners head on love affairs with reading activities, namely the emotional and intellectual aspects. This paper examines the engagement between the cognitive activities or the didactic process in the reading children literature and the connection between emotional and intellectual aspect or literary engagement. The notion of the comparative children literature is chosen as the reading materials because there are some profound element in it such as the adaptation and the transfer. The learners learn how among the children works in the world intertwine each other and have the dialogic process. As the comparative children literature, the learners unavoidably read their own traditional children stories too before they compare it with the stories from the different countries. The social and cultural point of view is the basic element finding its uniqueness among the stories.
\end{abstract}

Keywords: children literature, didactic, literary engagement, comparative children literature. 


\title{
Srovnávací dětská literatura: estetický a didaktický kontext
}

\begin{abstract}
Abstrakt
Četba dětské literatury není pouze rozvíjení kognitivních aktivit žáků ve třídě, ale zahrnuje také dva důležité aspekty přispívající k pozitivnímu vztahu žáků k čtenářským aktivitám; a to aspekty emocionální a intelektuální. Tato práce zkoumá vztah mezi kognitivními aktivitami a didaktickým procesem při četbě literatury pro děti a souvislost mezi emocionálním a intelektuálním aspektem a literárním zapojením. Srovnávací dětská literatura je zvolena materiálem ke čtení, protože se zde objevují prvky jako adaptace a přenos. Studenti se naučí, jak se mezi dětmi pracuje ve světě se vzájemným dialogem. Žáci nevyhnutelně přečtou své vlastní tradiční dětské příběhy, než je srovnají s příběhy z různých cizích zemí. Sociální a kulturní hledisko je základním prvkem při hledání jedinečnosti mezi př́běhy.
\end{abstract}

Klíčová slova: dětská literatura, didaktická, literární angažovanost, srovnávací dětská literatura.

\section{Introduction}

For years, there was some questions coming out connected with the children literature particularly the definition of children literature, is it the works for children or is it the works written by children. When we read the popular story such Snow White for some reasons it could be categorized as the children story, but sometimes it could be for adult at the same time. As one of the story from the Grimm's collection, Snow White has been considered as one of the most popular children story in the world, as the consequences it has a lot of versions in their picture books as well as the movies. The original version of Snow White in Grimm's book has little bit differences with Disney version for an instance.

The aim of children story firstly is how to make an enjoyment for them. It is very important notion in the children literature, because the children world must be pleasure and taken away from the pressure. Since its aim is an enjoyment, the children stories should consider the appropriate themes in line with the childhood life. The choosing of the themes is the substance way in children stories due to its consideration in sociocultural, identity and pedagogy. Thus, the stories do not only rely on its exciting theme and plot but also it should be containing the education and reflecting the identity as a result of the socio cultural process for the children. 


\section{What is children literature?}

Referred to the definition of children literature, Lynch-Brown and Tomlinson (1999) are defined children literature as good-quality trade books for children from birth to adolescence, covering topics of relevance, and interest to children of those ages, through prose and poetry, fiction and non-fiction (p. 2). Many children stories are scattered around and it can be easily found today, but not all of such children stories are suitable for the children mental development. In this case, the theme including the content of the stories should be becoming the salient consideration to choose the best stories according to the level of an age. For example the theme, it is truly essential problem in the way of choosing the stories for children.

The themes in the children stories usually are the childhood world and problem such as telling their new toys and pets, talking the scary things like the ghost, their excitement of the new friends and school, and so forth. Or, the themes can also be the common themes that are loved by the children, like the imaginative themes about big dragon, giant lizard, and dinosaur till the super hero. The sentimental problems and other rough themes are inappropriate for the children, because such themes are not engaging with their world and ages, like the suicide, love stories, and so forth. Further, Hunt (2005) gives the more detailed definition of the children stories and book, Children's books are different from adults' books: They are written for a different audience, with different skills, different needs, and different ways of reading: Equally, children experience texts in ways which are often unknowable, but which many of us strongly suspect to be very rich and complex (p. 3).

\section{Didactic and Children Literature}

Folktales as well as fairy tales are used as the vehicle of didacticism, they can deliver and convey the values of one society, like social, historical, religious and moral values. They are the effective instruments to keep and maintain the tradition from one generation to the next generation. Because mostly folktales are the oral tradition, so that the parents can tell about these stories to their children before sleeping or in other leisure time. Thus, the future generation can be understood the root of tradition as the product of the local genious due to its unique that make it differ from other society. Folktales as the great heritage of one culture should be conveyed to defend the characteristics of the society. Folktales/fairy tales is the fruit of the cultural process and experiences of one society. That is why the oral tradition is strongly believed and told from one generation to the next generation. Brother Grimm tales as an example was published firstly in 1812 as the literary fairy tales, but eventually the oral tradition has been existed hundreds years in Germany and Europe before. The oral tradition process is also connected with 
the universality context or in Jack Zipes term called cultural transmission. The folktale/ fairy tale is interconnected with other stories from the whole parts of the world. There is the dialogic process among of them. Such as Yeh Hsien or well known as Chinese Cinderella was found in 618-907 AD during the Tang Dynasty in China, and transform it into literary tradition in $9^{\text {th }}$ century by You Yang. In Europe this literary tradition found it in Charles Perrault tales published in 1697 or around 8 centuries after the Chinese Cinderella. It was such a long dialog and process in cultural adaptation and transmission. The adaptation and the transformation from the oral tradition to literary tradition is a kind of effort to bring the oral tradition into the pedagogic context besides it also is very useful to preserve the richness and the diversities of the culture.

\section{Children Literature: Oral to Literary Tradition}

Reynolds (2004) argues children's literature's long association with education, acculturation and approved behavior also marks it as a body antithetical to much of what youth culture stands for. While today not many of parents have a plenty of time telling some of children stories to their sons also the development of technology and the needs of children have been changed. Thus, the oral tradition mostly moves to the reading tradition even the digital tradition. The strengths of the reading text tradition are caused of these several phenomena:

1. In text/ reading tradition, the story usually comes together with the illustration, surely it will attract and entertain the children to read

2. Not all of parents knowing the traditional stories, but it is not their barrier because they can read for their children

3. Parents can select the suitable stories for their children

4. Text usually is more interesting because it has been modified by the author

The children literature which is transferred in book for instances folktales including fairy tales, myth, and legend. The term tale is originated from an old English word "talu" that has the meaning speech. It is because the tales are told from one to another, from the older generation to the younger generation, and it is usually anonymous and short. A tale depicts something wonderful, astonish, and metaphysics, thus the development of characters is not a salient notion like in the text story such as short story and novel. Kennedy and Gioia (2010) states that "tales" is pretty much synonymous with "yarn", for it implies a story in which the goal is relevation of the marvelous rather than relevation of character (p. 11). Tales are much more charming and entertaining with the moral teaching content.

Then the literary approach of the folktales/fairy tales examines the stylistics features and the thematic significance of the tale of genre and its historical development. 
Adopting from the new criticism theory, Max Luthi suggested examining the form and the structure of the folktales/fairy tales as the unity. Luthi in Zipes (2000) argued fairy tales contain essential underlying meanings which, in so far as form and meaning are thought of as integral, are manifest in the basic style of the fairy tale (p. 18). Luthi examines the tales' motif and the story elements for instance plot, character, characteristics, setting, figurative languages, theme etc. and ignores the social and cultural context of the story. Like the principles of the new criticism, Luthi approach of the folktale/fairy tale ranges from the specific features to the general. The analyzing of the particular elements points to the general meaning and the understanding of the stories' genre. Further Luthi in Zipes (2000) stated specific features are discussed in so far as they are typical of the genre and can be used to assert abstract general ideas (p. 18). This approach begins with the textual close reading then it will interpret and observe its form and literary elements. Hence, the folktales/fairy tales here are not from the oral tradition but literary tradition.

\section{Contact, Transfer, and Reception in Children Literature}

The discourses of comparative children literature somehow could not separate with the social and cultural interrelationship across the nations. A lot of children literature works since in the past time were engaging with the different cultures. The interrelation of one and other folktales/fairy tales across nation are connected with the contact of the author, publisher, translator, and among literary works themselves. The adaptation will carry out during the translation, correspondence among the authors, the trip to other countries, and also through the other contacts.

The history of the multilateral influences in the field of children's literature has not yet been written. Except for a few single attempts to give a survey of the adaptations and translations the one or other literary work has gone through, nobody has ever tried to make a comprehensive analysis from the very beginning portraying not only the factual exchange between two national children's literatures, but giving also the documentation on how the translations have been accepted, how readers, critics, book selectors evaluated them - and how the function of the texts were [sic] changed by adaptation and translation tendencies, how their reading and their influence have been reflected in memoirs and biographies (Scherf in Sullivan, 1976, 62).

Mostly the authors of children literature are also the translator hereby they translate myriads of stories from other different multicultural countries into their languages. These processes of translation at the same time will affect to the style and also the cultural adaptation to their stories that they wrote. Or they include some of the cultural, setting, characters from other multicultural stories into their own works. For example in the Snow White story from Brother Grimm version, it was found the multicultural 
elements like ebony tree. It used to describe the window of the palace and snow white hair, "her hair was as black as ebony". Particularly ebony tree is only found in tropical rainforest in some countries, such as in India, Ceylon, Indonesia and Gabon. But, how is the ebony tree came to European fairy tales? The answer definitely will be associated with the contact and transfer of culture among the countries. While in Walt Disney version, the story of Snow White has different color of hair, because the color in Walt Disney version was not as black as ebony but it was a little bit change by combining with grey, because it was unnatural and harsh. Therefore from the color of hair Snow White also has the differences from one to another version.

\section{Comparative Children Literature: The Adaptation of the Swan Maiden, the Three Swans, the Golden Hill and the Madura Folktales Aryo Menak (ATU 400)}

The stories of ATU number 400 was The Man on a Quest for His Lost wife and it had myriads of variants all over the world. One of the most popular was the Swan Maiden. This folktale had many different titles but they have the similar motifs. The Swan Maiden in European version by Joseph Jacob (ed.) had the seven Swans and the hunter as the trickster. The hunter took the youngest and the smallest swan's robe and hid it while they bath on the lake. Six of the swans could change the form from the maidens into the swans but not for the youngest one. Then she married with the hunter and lived together till they had two children, one boy and one girl. Though she lived happily but she was longing for her home, then one day when she played hide and seek with her children, she unintentionally found her robe. She told her children if their father really loved her she must look for her in the land east o' the sun and the west o' the moon. He came home and surprised, then he went for his journey searching his wife.

This version of the story has three helpers, mainly the old man who was eventually the king of Beast. The other was the old man brothers, the king of birds and the king of fish. By helping from the dolphin, the hunter had finally known the place where his wife lived and it was in the castle on the top of the crystal mountain. In the middle of journey he met two people arguing and fighting for the magic cap and shoes as the legacy from their parents. The hunter cheated them and took it as his magical flight to carry him on the top of the crystal mountain. The use of two magic objects (the cap and the shoes) mostly emerged in this variant hereby this variants was combined with ATU number 313 about the magical flight. The use of magical objects also risen up in German tale the Three Swan and Czech tale by Nemcova, the Golden Hill. At last, the hunter could accomplish on the top of the crystal mountain and asked to the king for his wife. The king gave the condition to the hunter, he would hand his daughter but 
he must recognize her only in one chance. Luckily, he could recognize her by noticing her mark of her right forefinger because of her little wound of the needle when she was sewing her children clothes in the past time. They returned to the hunter's house and lived happily.

The Three Swans retold by Ernst Meier had three swans as the maidens otherwise the trickster was also the hunter. The magic helper was also the old man but only one old man, but he solved every the hunter problem. The status of the maiden in this story was as the hunter second wife, because his first wife had been died. He was longing for his first wife and he fully deserved in his life to marry with the woman same as his first wife. The maiden here was the youngest maiden either. With the old man help, he could get the maiden as his wife and had several children and lived for fifteen years together before her wife was leaving him after she found her robe. Like another version, he also searched his wife and the old man gave him direction. Then, he got three tasks to fulfill if he wanted to redeem his wife. The three days tasks were fighting with the three dragons. He successfully passed the tasks and redeemed his wife. This version has different combination, because there was no magical object but it has other combination with ATU number 401a for the tasks and ATU number 302 due to his successful for the tasks and his wife redeeming.

The complete one of ATU number combination from this tale is the Golden Hill, Czech fairy tales rewritten by Bozena Nemcova. The Main motif (ATU number 400) is the same as the other stories with the basic adaptation of the Swan Maiden. Otherwise Nemcova combines it with some of the variants and motifs to make it much more interesting. The trickster is also different with the majority of European Fairy tales because here the trickster name is Libor, the gardener who lived with his old widow mother. Like the Swan Maiden and the three swans Libor was pulled out one of the swan veil when three of them were swum in the pond. The most beautiful maiden was the youngest or the last either, named Cekanka. As the other stories, Cekanka found her veil only in one day thereby they did not marry yet but they fell in love each other. She returned to her castle and leaved Libor after she persuaded Libor old mother showing her veil. The motif of the magical helper looks a like the Swan Maiden, three brothers, here they were the gamekeeper who belongs the competence calling the crows asking the information. The characteristics of Nemcova tales were shown in this part there was the level of difficulties or the steps of conflict such as the first gamekeeper called a hundred crows, the second one called two hundred and the last one called three hundred crows. Libor was achieved the solution in the last gamekeeper with the lymph crow (ATU 222 about war between birds or insects with quadruped).

The Golden Hill has the dominant magical flight in some parts of the story (ATU 313). The first magical object is the corn using to grow up the oak tree from the ocean when the crow carrying Libor to the Golden Hill. This giant oak tree is used to rest for three times. Secondly, the magical object is the saddle that is used to reach the golden hill. 
Libor got it by cheating two fighting giants. This fairy tale combines with ATU 465a when Libor has come to the castle and ask for Cekanka. Later on, Cekanka's mother, the wicked witch gives him the impossible tasks (ATU 465a: The man persecuted because of his beautiful wife). The first task he must collect a hundred fathoms of wood using his wooden axe only in one night, the second is he must collect all water in the pond and put it on the top of the hill with two pails only in one night, and the last task is he must pasture three hundred hares in the meadow and if he losses one of them then the witch will kill him.

Libor was success to fulfill his impossible tasks with Cekanka helps otherwise the witch hardly try preventing Libor to bring her daughter (ATU 310: The Maiden in the Tower). Cekanka hereby deceive her mother by covering her head and Libor's with her veil. Further, they flee from the castle (ATU 313). The witch pursues them and for three times they deceive her. First Cekanka transform herself as the chapel and Libor as the pulpit on it. The next, Cekanka changes into the flower and Libor into the bush. By the end, Cekanka transforms into the swan and Libor into the pond. The witch knows them then she changes herself into the cow and drinks all of the water in the pond. The water is too much drinking the water thus she is blasting. The water returns back into the pond. The witch dies and the remained thing is only the cow carcass. Both lovers become the human again and they go home to marry and they live happily (ATU 401a: The Soldier in the Enchanted Castle).

On the other hand, Madura folktale, Aryo Menak is one of Indonesia tale with ATU 400, the similar title is Jaka Tarub from Java island. This story is combined with ATU number 413, the Stolen Clothing and also ATU number 313, The Magic Flight. Aryo Menak was the young farmer who want married but he could not find any girl who he loved. Till some day in his journey he heard the splashed water and closed it to have a look. He found seven angels bathed in the lake. He took the youngest one shawl and hid it. The six of angels could return back to the paradise but the youngest one. He pretended helping her, brought her to his house, and married her. This couple had son and lived for long time till one day Aryo Menak broke his wife rule. She reminded him not to stalking when she was cooking in the kitchen. Because using her magic power, she could cook one seed of rice became one pan of rice. Otherwise Aryo Menak was curious and stalking. His wife lost her magical power and she took the rice from the barn till she found her shawl in there. She took her shawl and returned back her husband and son on the earth.

These Story motifs are less completed comparing with Nemcova story. The combination with ATU number 413 is tightly connected but not really strongly connected with ATU 313 but at the beginning part when the seven angels came to the world and bathed in the lake. Another different motif is the ending of this story. The ending is definitely different with others in ATU number 400. Mostly the similar stories have the combination with ATU number 302, 310, 402a when the main character successfully 
accomplishes the tasks and married with the princess or the angel. Or, it is probably with ATU 313 when the main character uses the magical flight to flee his princess from the wicked witch. The ending in Aryo Menak is sad ending when the angel is left him and his son on the earth and returned to the paradise.

\section{Conclusion}

The children literature particularly comparative children literature unavoidably is connected across nation and it has its own universality. The similarities of some stories from the different world have been proved the dialogic process in the comparative children literature notion. The theme is also an essential part in the comparative children literature due to its pedagogic and didactic aims in children literature. Hereby, the discourse of children literature particularly comparative children literature is not merely discussing the literary aspects such as the figurative language but it also discusses the educational aspects for the children. Some of the children stories for an instance has been modified from its original version because some of the parts in the story are not suitable for the children.

\section{References}

Dixon-Kennedy, M. (1998). Encyclopedia of Russian \& Slavic myth and legend. Santa Barbara, Calif: ABC-CLIO.

Němcová, B., Erben, K. J., \& Müllerová, L. (2008). Czech fairytales. Praha: Vitalis.

Gray, L. H., Macculloch, J. A. \& Machál, J. (1918). The Mythology of All Races. Celtic and Slavic. Boston: Marshall Jones.

Grenby, M. (2004). Children Literature. Edinburg: Edinburg University Press.

Grilli, G. (1997). Myth, Symbol, and Meaning. New York: Routledge.

Hakemulder, J. (2000). The moral laboratory: Experiments examining the effects of reading literature on social perception and moral self-concept. Amsterdam: J. Benjamins Pub.

Hunt, P. (ed.). (2003). Literature for Children. London: Routledge

Luthi, M. (1982). European Folktale: Form and Nature. Bloomington: Indiana University Press.

Lynch-Brown, C., \& Tomlinson, C. M. (1999). Essentials of children's literature. Boston: Allyn and Bacon. O'Sullivan, E. (2005). Comparative children's literature. Abingdon, Oxfordshire: Routledge.

Reynolds, K. (January 01, 2004). A review of youth cultures: Texts, images and identities [Book Review]. Papers: Explorations into Children's Literature, 14, 1, 60-62.

Sherman, J. (2008). Storytelling: An Encyclopedia of Mythology and Folklore. Armonk, N.Y: M.E. Sharpe.

Uther, H.-J., Suomalainen Tiedeakatemia, \& Folklore Fellows. (2004). The types of International Folktales. Helsinki: Academia Scientiarum Fennica.

Zipes, J. (January 01, 1987). Fairy Tale as Myth/Myth as Fairy Tale. Children's Literature Association Quarterly, 1, 107-110. 


\section{Contact:}

Imron Wakhid Harits, Ph.D.

Trunojoyo University of Madura, Indonesia

Jl. Raya Telang Po. Box 02 Kamal, Bangkalan, Indonesia

Email: imronwakhidharits@gmail.com

Imron Wakhid Harits works as Assistant Professor at the Trunojoyo University of Madura in Indonesia. He was studying the English language and literature at the University of Jember and State Surabaya University. His research topics are children literature, folktales, communicative reading and comparative children literature. 